\title{
THE ROLE OF TERTIARY EDUCATION IN REGIONAL DEVELOPMENT IN CONDITIONS OF SLOVAK REPUBLIC
}

\begin{abstract}
Radomíra HORNYÁK GREGÁŇOVÁ, Department of Mathematics, Faculty of Economics and Management, Slovak University of Agriculture in Nitra, Tr. A. Hlinku 2, 94976 Nitra, Slovak Republic; radomira.greganova@ uniag.sk (corresponding author) Dana ORSZÁGHOVÁ, Department of Mathematics, Faculty of Economics and Management, Slovak University of Agriculture in Nitra, Tr. A. Hlinku 2, 94976 Nitra, Slovak Republic; dana.orszaghova@uniag.sk

Jarmila HORVÁTHOVÁ, Department of Foreign Languages, Faculty of Economics and Management, Slovak University of Agriculture in Nitra, Tr. A. Hlinku 2, 94976 Nitra, Slovak Republic; jarmila.horvathova@uniag.sk

In addition to the infrastructure of the regions, an essential aspect of their development is their educational structure and the demographic potential according to the predominance of the age composition. The education is basic tool for acquiring expert knowledge, which affects human capital of the labor market and professional mobility and adaptability of human resources at the labor market. It is important to educate the university undergraduates for practice by using appropriate and suitable educational methods. In Slovakia the share of inhabitants with the university education is increasing. This group represents the development potential of the regions. Great possibilities consist in the training of a new generation of graduates for different fields of regional development. Therefore, the educational structure and also the active working and networking of universities with other actors in the region are important. The objective of this paper is focused on the tertiary education and study programs for the regional development. We will analyze the development of number of students at universities with regard to the individual levels of study (bachelor, engineer/master and $\mathrm{PhD}$.) and study programs within the individual regions of the Slovak Republic. The evaluation of the obtained data will be made by using the methods of comparative statistics.
\end{abstract}

Keywords: tertiary education, study programs, students, regional development, labor market

\section{INTRODUCTION}

Education and professional training are vital for the economic and social progress. The harmonization of the skills and the requirements of the labour market is significant. These aspects are more and more important in the globalized and knowledge economy which needs the qualified labour force to be able to compete in the area of productivity, quality and innovations. The key objective of the strategy Europe 2020 is related to the tertiary education, at least at the level 40 $\%$ of the population at the age of $30-34$ years, who will complete the tertiary or equivalent education until 2020 . In the countries of the EU-28 the proportion of the persons with the tertiary education was growing rapidly from the level $23.6 \%$ in 2006 (the beginning of the time line for the EU-28 countries), where every year the growth of the proportion was recorded. Until 2015 the tertiary education was achieved by about $38.7 \%$ of inhabitants at the age of 30 - 34 years, which was 0.8 of the percentage point more than in 2014. As the majority of population the age of 30 - 34 years completes their tertiary education till the age of 30 , this indicator can be used for the evaluation of the attractiveness (or " attractiveness

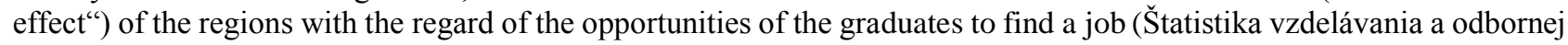
prípravy na regionálnej úrovni, 2016).

The level of education could be associated with many productivity improving factors, which will be reflected in the quality of inhabitants' life in the particular region. The tertiary education has the substantial impact on the regional development. Its effect is being studied by many researchers within the European region provided that the high average levels of human capital throughout the economy increase the productivity of any given worker (Di Liberto, 2008).

In the process of education the human resources acquire their own knowledge, proficiency and attitudes. Fitz-Enz (2000) defines the human capital as the inherent features brought by an employee:

- in the working process (intelligence, stamina for fulfillment of the job tasks, positive approach, reliability, responsibility),

- ability to learn (talent, imagination, creativity, ability of "know how"),

- motivation to share information and knowledge, team spirit and resolution.

Copyright (C) 2017 The Authors. Published by Aleksandras Stulginskis University. This is an open-access article distributed under the terms of the Creative Commons Attribution License (CC-BY 4.0), which permits unrestricted use, distribution, and reproduction in any medium, provided the original author and source are credited. 
The education influences the development of regions. The significant events from the Slovak history make it evident, however, this statement holds true in general. The regions are the fundamental place for the knowledge creation and acquisition. The idea of the learning region originated on the basis of several publications dealing with the national systems of innovations. They defined the notion of the learning economy (Lundwal, 1992; Hudec et al., 2009). The economic growth at the national and regional level depends on the innovations and the innovations are based on the creation, implementation and application of knowledge. The regional development plays an important role in the development of the particular territory, it also participates in the fulfilment of economic, social and environmental functions of a country (Papcunová et al., 2015). The innovations are considered to be the engine of economic development worldwide. Universities and companies are the main subjects in the society that predetermine the quality of human potential and development of knowledge based economy (Cifranič, Valach, 2017). In each region it is possible to find the unique combination of factors for its differential development. The inhabitants represent the producers and at the same time also consumers in the relation to the economic development. Therefore, its qualitative and quantitative characters as well as the population mobility (Papcunová, Gecíková, 2012) and also the demographic changes in the population structure are essential (Országhová, 2017).

The interesting results are being offered by the studies from the area of wellbeing analysis which is related to the regions; generally wellbeing can be defined as a contented state of being happy and healthy, and prosperous. The question whether social capital in the rural areas differs from the social capital in the urban areas of the region (case of the Lubelskie Voivodeship in Poland) is analyzed in publication of Vaznoniene, Vaznonis (2015). The different wellbeing components (objective and subjective) enable to evaluate the progress of the regions in various domains of life as well, to reveal and understand the major problems, to present references about the expedient problems for the solution of those problems. Wellbeing analysis at the regional level is recognized to be an important part concerning a better standard of living of the local population and the whole regional development. The indicators/evaluations show whether the situation in a region is in progress, stable or regresses.

The proposal of the national program for the learning regions in the Slovak Republic (Národný program pre učiace sa regióny, 2007) claims the basic characteristic, which states that there are the significant differences between the regions of the Slovak Republic in the indicators like GDP per capita, unemployment rate, labour productivity, etc. In the proposal the regional development in SR contained the necessity of cooperation by means of the support of the National Program Learning Regions. The cooperation and collaboration of the significant subjects in the field of the life-long education at the regional and local level contributes to the development of economy, creation of job opportunities and increase of employment in the particular region. From the viewpoint of the regional policy of SR it is necessary to emphasize the following objectives in the regional development:

- to create the motivational environment for the development of entrepreneurship,

- to support the innovative processes,

- to stimulate the creation of new job opportunities,

- to optimize the networks of educational system according to the needs of labour market,

- to create the prerequisites for the increase of availability and quality of the educational, consulting and information services.

One of the essential factors of the regional development in SR is the continual support of education in regions, predominantly in the area of the increased quality of content, the improvement of availability to education for all persons and interconnection of education and labour market. The vital factor is the creation of the firm partnership of the key institutions at the regional level and the enhancement of relations between them. There are the following institutions:

- all types of schools and educational institutions in region,

- institutions of further education,

- municipalities and communities,

- offices of labour, welfare services and family,

- school founders,

- employers, professional associations and chambers,

- non-governmental organizations (Národný program pre učiace sa regióny, 2007).

\section{RESEARCH METHODS}

On the basis of the elaborated theoretical outlines and the elaborated strategic document "National Program for Learning Regions", according to which there are significant differences between individual regions in the assessment of macroeconomic indicators, which are closely related to the education of the population, we have identified research problems. The research problem of this paper is related to the question - whether there exist the mutual relationship between the tertiary education in the particular region of SR and its economic development based on the employment/ or unemployment in the region. The research object is the location of universities in the SR in the relation to the particular region and the current data of unemployment in the regions of the SR. We will examine this relationship on the basis of partial tasks:

1. to analyze the number of universities in the each regions of the SR. In the SR it is possible to can be obtained the higher education not only on the public universities, but also on the private and state universities. Significant differences between individual types of universities present the form of their financing. Public and state 
universities are largely funded by public funding, private universities are financing from private sources. That is why we assume, that private universities will be more represented in economically advanced regions.

2. The educational structure of the population determines the development of the regions. An important aspect, however, is not just the educational structure, but for the regional development is more important the presence of the people who are educated in the regional development. In this context, we also looked at the offer of higher education in the field of public administration and regional development.

3. The unemployment rate is closely related to the educational structure. It can be assumed that higher access to the higher education in the region (university presence directly in the region) may also result in lower unemployment rate. From the point of view of employing graduates in the labor market, graduates represent the smallest group of unemployed people because they are very flexibly. So we analyze the unemployment rate in the regions in relation to the location of the universities in the region.

Based on the analysis of the detected data we will to predict the development of the tertiary education in relation to the development of regions, or to state the advantages and disadvantages on the education market in the current situation.

The issues provided in this contribution are based on the analytical view and evaluation, exploring the importance of the tertiary education in the regional context of the Slovak Republic. The first applied method is the analysis and synthesis of the scientific literature. The following social research methods are the qualitative and comparative analysis of quantitative data and comparative analysis. The purpose of qualitative research is by Kozlovská- Bašková, 2015) is to identify the cause of the phenomena examined, motives and attitudes leading to a particular behavior. Usually it serves as a supplement to quantitative knowledge. According to authors we use for analysis whole process of qualitative research (preparatory phase and realization phase). For data collection we used the document analysis technique. Vanoch et al, (2009) under the document analysis, understand studying any materials that will help to better understand the necessary information. As part of quantitative research, we used the secondary data analysis. All data sources used in the research are indicated in the resources, or the tables with the elaborated data.

\section{RESULTS AND DISCUSSION}

In the following parts we will state the results and their analysis.

In the first part we will deal with the university education in the Slovak Republic (SR) in the relation to the particular regions. The latest complex accreditation of universities in the SR was pursued in 2015. The data in the Table 1 indicate that in Slovakia there are 35 tertiary institutions (in 2017). Out of them 20 are the public universities, 3 are state universities and 12 are the private tertiary institutions. The majority of universities - 13 - are located in the Bratislava region. The smallest number of universities is in the Prešov region. Apart from it 6 foreign tertiary institutions provide the tertiary education in Slovakia.

The data show that the center of the university education is concentrated in the capital city of the SR - in Bratislava. To the reflection of the third role of universities Hanová et al. (2016) claim that Bratislava`s university (University of Economics in Bratislava and Comenius University in Bratislava) emphasize more their national and international position and impact rather than the impact in the regional aspect. They want to hold so called national identity and develop the image of the national and international universities. The activities in favor of the region are not embedded in their strategic documents.

Table 1. Tertiary education in regions of SR (current situation in 2017)

\begin{tabular}{|l|c|c|c|c|}
\hline Region & Public universities & State universities & Private universities & Total in regions \\
\hline Bratislava & 5 & 2 & 6 & 13 \\
\hline Trnava & 2 & - & 2 & 4 \\
\hline Trenčin & 1 & - & 2 & 3 \\
\hline Nitra & 3 & - & - & 3 \\
\hline Žilina & 2 & 1 & - & 3 \\
\hline Banská Bystrica & 3 & - & - & 4 \\
\hline Prešov & 1 & - & 1 & 1 \\
\hline Košice & 3 & - & $\mathbf{1 2}$ & 4 \\
\hline Total in SR & $\mathbf{2 0}$ & $\mathbf{3}$ & $\mathbf{3 5}$ \\
\hline
\end{tabular}

Source: https://www.portalvs.sk/sk/, own processing

Out of the total number of universities, most of them are the public universities $(57.14 \%)$. The state tertiary institutions are: the Armed Forces Academy of General Milan Rastislav Štefánik in Liptovský Mikuláš, the Academy of the Police Force in Bratislava and the Slovak Medical University in Bratislava. The Armed Forces Academy rangs under the authorization of the Ministry of Defence of the SR, the Academy of the Police Force under the Ministry of Interior of the SR and the Slovak Medical University under the Ministry of Health of the SR. A great number of the tertiary institutions is usually located in more developed regions and the residences of universities are mostly concentrated in the urbanized centres. The Table 1 shows these data. Therefore, it is clear that the majority of the tertiary institutions are placed the Bratislava region, on the contrary, the least number of them are in the Prešov region. In general, it is possible to state that the public tertiary institutions are located in each region, which creates the prerequisites for the rather balanced availability of the higher education in the regions. The residences of the private tertiary institutions are allocated mostly in the more developed regions. One of the reasons is that in these regions there is a higher potential of the future students. Another argument is that the availability of the technical and social infrastructure plays the significant role in the process 
of allocation of these institutions. The explanation is that the private tertiary institutions represent the private firms and for those the limiting factor is the transportation availability and the presence of the technical and social infrastructure in the particular location.

In the second part we will study the study programs targeted at the regional development in the SR. The Table 2 indicates the survey of the planned number of students of the study programs aimed at the regional development at the particular universities.

The important subjects of the regional development are the representatives of the territorial self - government at the regional or the local level. From this aspect their educational structure becomes often the limiting factor of the further development. Tej, Šimková (2010) claim that the specialists in the territorial self - government should represent the most educated specific group of employees, whose job promotion should have the defined rules set by the law, a certain disciplinary responsibility, specific rights and duties.

Table 2. Study programs and planned number of students in SR in 2018/2019 (only public universities)

\begin{tabular}{|c|c|c|c|}
\hline \multirow[t]{2}{*}{ University } & \multirow[t]{2}{*}{ Study program } & \multicolumn{2}{|c|}{ Number of students } \\
\hline & & Full time form & Part time form \\
\hline \multirow{3}{*}{$\begin{array}{l}\text { University of Economics in } \\
\text { Bratislava }\end{array}$} & Public administration and regional development (bachelor) & 35 & - \\
\hline & Public administration and regional development (master) & 35 & - \\
\hline & Public administration and regional development (PhD.) & 1 & 1 \\
\hline \multirow{4}{*}{$\begin{array}{l}\text { Slovak University } \\
\text { of Agriculture in Nitra }\end{array}$} & Regional development and policies of the EU (bachelor) & 60 & 20 \\
\hline & Regional development and policies of the EU (master ) & 45 & 15 \\
\hline & $\begin{array}{l}\text { Rural development and development of rural turism } \\
\text { (master) }\end{array}$ & 60 & 20 \\
\hline & Integrated rural development $((\mathrm{PhD})$ & not given & not given \\
\hline \multirow{2}{*}{$\begin{array}{l}\text { University of A.Dubčeka in } \\
\text { Trenčín }\end{array}$} & Regional economy and development (bachelor) & 50 & 50 \\
\hline & Public administration (bachelor) & 50 & 50 \\
\hline \multirow{2}{*}{$\begin{array}{l}\text { University of Mate Bela in } \\
\text { Banská Bystrica }\end{array}$} & Territorial management (bachelor) & 30 & - \\
\hline & Territorial management (master) & 30 & - \\
\hline \multirow[t]{2}{*}{$\begin{array}{l}\text { Technical University of } \\
\text { Košice }\end{array}$} & $\begin{array}{l}\text { Economy and management of public administration } \\
\text { (bachelor) }\end{array}$ & 40 & 30 \\
\hline & $\begin{array}{c}\text { Economy and management of public administration } \\
\text { (master) }\end{array}$ & 40 & 30 \\
\hline
\end{tabular}

Source: https://www.portalvs.sk/sk/, own processing

From this viewpoint the considerable aspect is the availability of the higher education in this area. The Table 2 indicates that out of 8 regions in the SR it is possible to study the specialization of the public administration, or the regional development and economy in 5 of them, which represents $25 \%$ of the total number of the public universities. Despite the fact that the planned number of the enrolled students does not meet fully the requirements of education in this area, we can consider these numbers to be sufficient. The graduates of these study programs are employed predominantly in the state administration or the municipality, or directly in the organs responsible for the regional development in the particular area, e.g. the Regional development agencies. The legislative requirements related to the employees in the public administration and regional development do not specify exactly the particular study program which the applicant for the job in this field should have graduated from. We consider it to be the negative because in the public administration the graduates from universities are employed, however, they did not study the public administration.

Table 3. Current unemployment rate in regions of SR

\begin{tabular}{|l|c|c|c|}
\hline \multirow{2}{*}{ Region } & Total unemployment rate & \multicolumn{2}{|c|}{ Number of job seekers (university graduates) } \\
\cline { 3 - 4 } & & December 2016 & December 2015 \\
\hline Bratislava & $3.87 \%\left(2^{\text {nd }}\right.$ place $)$ & 305 & 433 \\
\hline Trnava & $2.97 \%\left(1^{\text {st }}\right.$ place $)$ & 273 & 406 \\
\hline Trenčín & $3.56 \%\left(3^{\text {rd }}\right.$ place $)$ & 438 & 537 \\
\hline Nitra & $4.55 \%\left(4^{\text {th }}\right.$ place $)$ & 457 & 705 \\
\hline Žilina & $5.08 \%\left(5^{\text {th }}\right.$ place $)$ & 568 & 529 \\
\hline Banská Bystrica & $9.17 \%\left(6^{\text {th }}\right.$ place $)$ & 410 & 1084 \\
\hline Prešov & $10.32 \%\left(7^{\text {th }}\right.$ place $)$ & 990 & 845 \\
\hline Košice & $10.48 \%\left(8^{\text {th }}\right.$ lace $)$ & 661 & $\mathbf{5 , 1 5 2}$ \\
\hline Total in SR & $\mathbf{7 . 5 9} \%$ & $\mathbf{4 , 1 0 2}$ & \\
\hline
\end{tabular}

Source: ÚPSVR, own processing

In the first column there is indicated the unemployment rate in the regions of the SR in September 2017 (\%). The unemployment rate in the SR calculated from the total number of the job seekers achieved $7.59 \%$ in September 2017. It 
was decreased by 0.11 of the percentage point in comparison with the previous month and by 3.24 of the percentage point in comparison with the previous year (according to the data from the Office of Labour, Social Affairs and Family).

The second column provides the number of the job seekers (university graduates) in the particular regions totally. We stated the data from 2015 and 2016 for comparison.

Recently the Slovak Republic is successful in reduction of the unemployment rate in the regions. The graduates do not belong to the group of unemployed which would create the significant rate. The majority of graduates is not registered in the list and many of them are registered only for a short time. The Table 3 indicates that the number of the unemployed graduates fell by $25.59 \%$ in a year. The highest decrease was monitored in the Košice region (decline by 184 unemployed), on the contrary, the smallest decrease was recorded in the Prešov region - by 94 unemployed. The employment of graduates on the labour market is limited not only by the development of the particular territory, but also by the completed study program of a graduate. Nowadays, on the Slovak labour market there is the insufficient number of the graduates from the technical specializations, on the contrary, there are many graduates from the humanities or social study programs.

From the viewpoint of evaluation of the further development in regions it is essential to monitor also the changes in the group of pre-productive population (at the age less than 15 years). This age group represents the potential labour force on the labour market and at the same time the potential applicants for the university study. According to Országhová (2017) the decrease was recorded in all the regions (apart from Bratislava region) of the population at the pre-productive age in the period 2000 to 2015 (Figure 1). The universities as well as the employers will have to draw consequences from this tendency.

This negative demographic development is also reflected at universities. The basic principle of financing of the tertiary institutions is the normative financing, i.e. depending on the number of students. As a consequence of the negative demographic development the number of inhabitants at the pre-productive age is falling, which is also reflected in the number of applicants for the university education. Therefore, the number of the university students is being decreased, which the negative impact on the amount of the eligible funding has received from the budget by the universities. The tertiary institutions try to solve this situation by the continual increase of quality of the educational process as well as the research process, which is interconnected directly with the practice, and thus it creates the prerequisites for the dual education. On the other hand, the new and attractive study programs are formed in order to attract more new students.

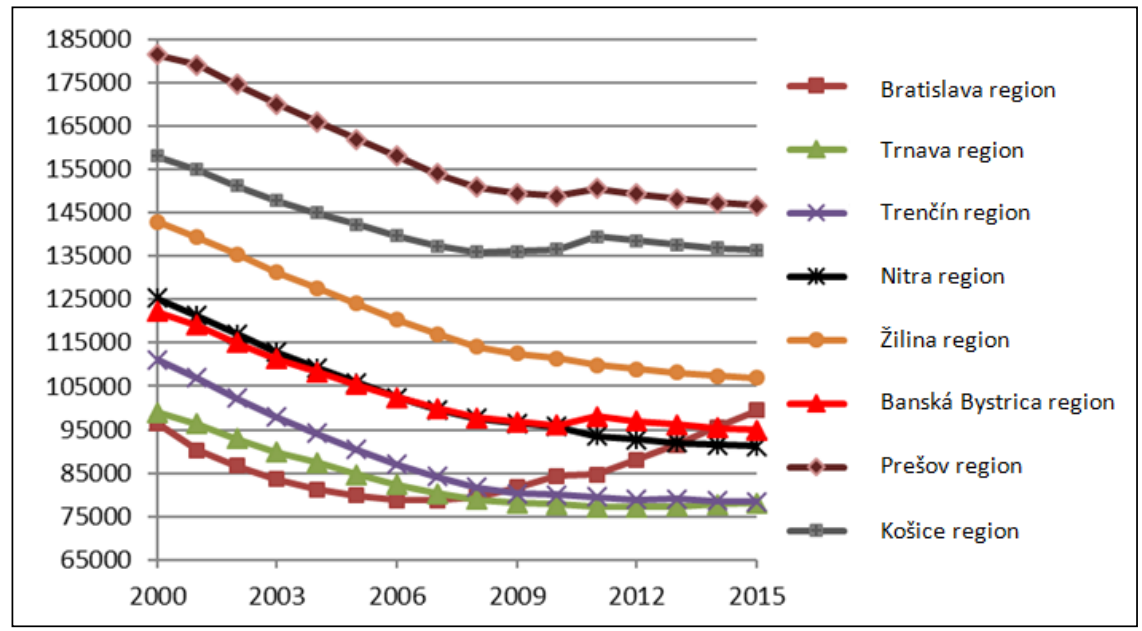

Figure 1. Demographic development of number of population at pre-productive age in regions of SR (2000 - 2015) Source: Országhová (2017)

Čierna et al. (2017) state that if an organization wants to develop, to improve, and to innovate its processes in this information era, it requires the management system that will maximize the use of human potential at its disposal and this can be achieved by establishing the culture of learning and continuous progress.

The contribution of the institutions of higher education to regional development is a theme that has attracted the growing attention in the recent years. The educational institutions are increasingly expected not only to conduct education and research, but also to play an active role in the economic, social and cultural development of their regions (Arbo, Bennewort, 2007). The authors of the OECD project entitled "Supporting the Contribution of Higher Education Institutions to Regional Development" takes into consideration the educational institution in a broader sense: by higher education they mean universities, university colleges and other institutions that provide a post-secondary education and which normally involve an element of research and development.

In order to achieve the required effects of the human capital in the form of economic development, its effective utilization must be guaranteed. The main determinants of the effective usage of the human capital are:

- the flexible functioning of labour market, or the creation of such conditions which allow a prompt adaptation of the labour force to the changing situation on the labour market,

- the flexible system of education, when it meet the needs of the labour market,

- the development of the life-long education, predominantly the attitude of the adult population to the different forms of the further education (Filipová, 2008). 
Gecíková et al. (2014) claim that the relatively high number of the educational institutions is involved in the process of education in the regions: universities, departmental and private educational institutions and agencies. Despite their diversity, there is absent their target focus, functional division of content and training scope as well as the whole coordination of the educational system of the representatives of the municipality.

Páleníková (2013) emphasizes that the main factors of the development of regions comprise the human capital and its effective usage. On the one hand, the education of inhabitants requires the high social and individual costs, on the other hand, it brings the significant individual and social benefits in the form of higher public revenues, a lower risk of unemployment, the lower social costs, the positive social environment, and last but not least, a higher productivity and prerequisite of the economic development.

\section{CONCLUSIONS}

The educated population is the motive force of the development of regions. The Slovak Republic makes an effort to create the prerequisites for the university education by the wide range of the study specializations and study programs at the public, state and private tertiary institutions. This is confirmed by the results of the research, which showed that the Slovak Republic offers higher education at 35 universities with representation in each region of Slovakia. This high availability of higher education also means that an increasing number of graduates of secondary schools are continuing their university studies every year. The positive result of this development is the increase of the educational level of the population, but the negative fact is that many graduates after graduation does not stay in Slovak Republic, but they going to abroad.

The differences in the educational structure in the particular regions are connected predominantly with their development. Despite the fact that in the less developed regions of Slovakia there is relatively good access to higher education, it is not always possible to find for graduates the work directly in the given region. This is also confirmed by the research results, where we find that despite the presence of universities in less developed regions (Banská Bystrica 3, Prešov - 1, Košice - 3), the unemployment rate is almost 10\%, which is well above the average of the Slovak Republic. A higher migration of the graduates is directed from the less developed regions to more developed ones. However, this kind of migration brings the negatives because this region becomes unattractive for the location of firms, as there is the shortage of the educated labour force. The next negative is the fact that the locations of the tertiary institutions are mostly in the regional capitals, or in the big cities and only a small number of the students returns back to their home region. As the human capital is one of the fundamental development factors of the area, the education of inhabitants acquires the strategic meaning not only for the development of the particular territory, but also for the country and society as a whole. Education rang among the basic objectives of the modern society. The vital part of education should be the formation of the working abilities and this is becoming the life-long process. The fundamental prerequisite for this process is the motivation of people to learn and study.

The urgency of lifelong education in Europe was determined by the increasing role of education in economies, which was caused by changes in the stage of economic development in the 21st century, transiting from an industrial economy to a knowledge economy. Therefore, the nature of the phenomenon of lifelong education in economic reality is associated with transition to a knowledge economy in which human knowledge becomes a real factor of production in a free market, generating high value added (Sannikova, Dobele, Dobele, 2015).

\section{REFERENCES}

1. Arbo, P., Benneworth, P. 2007. Understanding the regional contribution of higher education institutions: A literature review. $O E C D$ Education Working Papers, No. 9. https://doi.org/10.1787/161208155312.

2. Cifranič, M., Valach, M. 2017. Innovative approaches to system of education focusing on business. Proceedings of the " $X X$. International colloquium on regional sciences", pp. 264-271, Masarykova univerzita in Brno. https://doi.org/10.5817/CZ.MUNI.P210-8587-2017-33.

3. Čierna, H., Sujová, E., Hąbek, P., Horská, E., Kapsdorferová, Z. 2017. Learning organization at higher education institutions in the EU: proposal for implementing philosophy of learning organization-results from research. Quality \& Quantity, Vol. 51(3), pp. 1305-1320. https://doi.org/10.1007/s11135-016-0332-3

4. Di Liberto, A. 2008. Education and Italian regional development. Economics of Education Review, Vol. 27 , Issue 1, pp. $94-107$. https://doi.org/10.1016/j.econedurev.2006.08.004.

5. Filipová. L. 2008. Lidský kapitál a jeho efektívní využití jako zdroj ekonomického růstu v České republice. Studie národohospodářskeho ústavu Josefa Hlávky, č.3., Praha. [In Czech]

6. Fitz-Enz, J. 2000. ROI of human capital: Measuring the economic value of employee performance. AMACOM Div American Mgmt Assn.

7. Gecíková, I., Papcunová, V., Belajová, A. 2014. The quality measurement of management in local self-government in the Slovak Republic. In. Economic Annals-XXI., Vol. 9-10, No. 1, pp. 38-41.

8. Hanová, M., Moravčíková, D., Rehák, Š., Vozár, L. 2016. Posilnenie úlohy vysokých škôl v regiónoch. 1. vyd. Ministerstvo školstva Slovenskej republiky, Bratislava, p. 116. Available at https://www.minedu.sk/data/att/10143.pdf [In Slovak]

9. Hudec, O., Urbančíková, N., Džupka, P., Šebová, M., Klimovský, D., Suhányi, L., Želinský, T. 2009. Podoby regionálneho a miestneho rozvoja. Ekonomicka fakulta TU Košice. [In Slovak]

10. Kozlovská, M., Bašková, R. 2015. Zásady vedeckej práce. Modul Kvalitatívne metódy výskumu. Technická univerzita Košice, Available at https://www.svf.tuke.sk/wp-content/uploads/2015/06/Kvalitativne-metody.pdf [In Slovak] 
11. Lundvall, B. A. 1992. National systems of innovation: An analytical framework. Pinter, London.

12. Národný program pre učiace sa regióny (Návrh). $2007 . \quad$ Available at https://www.minedu.sk/data/files/2611_narodny_program_pre_uciace_sa_regiony.pdf [In Slovak]

13. Országhová, D. 2017. Labour-force participation rate in context of demographic changes in regions of Slovakia. Proceedings of the "XX. International colloquium on regional sciences", pp. 374-380, Masarykova univerzita in Brno. https://doi.org/10.5817/CZ.MUNI.P210-8587-2017-48

14. Papcunova, V., Gecíková, I. 2012. The population as an actor of development. Proceedings of the "XV. International colloquium on regional sciences", pp. 538-544, Masarykova univerzita in Brno.

15. Papcunová, V., Hornyák Gregáňová, R., Országhová, D., 2015. Evaluating of the financial management of the municipalities via parameters of data matrix in the Slovak Republic conditions. Proceedings of the "IX. International Conference on Applied Business Research ICABR 2014", pp. 803-814, Mendel University in Brno.

16. Páleníková, M. 2013. Vzdělávanání a jeho vliv na regionální rozvoj v ČR. Cibáková, V., Malý, I. Verejná politika a regionálny rozvoj, Iura Edition, Bratislava, p. 122-138. [In Czech]

17. Portál VŠ. Available at https://www.portalvs.sk/sk/ [In Slovak]

18. Sannikova, A., Dobele, A., Dobele, M. 2015. Effects of lifelong education and related factors on the competitiveness of countries. Proceedings of the International Scientific Conference "Rural Development 2015", Lithuanian University of Agriculture, Lithuania. https://doi.org/10.15544/RD.2015.105.

19. Štatistika vzdelávania a odbornej prípravy na regionálnej úrovni. 2016. Available at http://ec.europa.eu/eurostat/statisticsexplained/index.php/Education_and_training_statistics_at_regional_level/sk [In Slovak]

20. Tej, J., Šimková, H. 2010. Zvláštnosti v manažmente verejnej správy. Transfer inovácii. 18/2010, p. 144-150. (In Slovak)

21. Ústredie práce, sociálnych vecí a rodiny (UPSVR). Available at http://www.upsvar.sk/statistiky [In Slovak]

22. Vanoch, et. Al. 2009. Kuchárka amatérskeho výskumníka Bratislava: Iuventa, Available at https://www.iuventa.sk/files/documents/publik\%C3\%A1cie/kucharka_amaterskeho_vyskumnika/kucharka_amaterskeho_vysku mnika_na_web.pdf [IIn Slovak]

23. Vaznonienè, G., Vaznonis, B. 2015. The application of wellbeing research to regional level in Lithuania. Proceedings of the International Scientific Conference "Rural Development 2015", Lithuanian University of Agriculture, Lithuania. https://doi.org/10.15544/RD.2015.103 